\title{
An Evaluation on a Team Teaching by University Students and Lecturers in Australia
}

\author{
Sook Hee (Susan) Lee \\ Faculty of Business, Charles Sturt University Study Centre (CSUSC), Darlinghurst, New South Wales, Australia
}

\begin{abstract}
This paper documents the results of an evaluation of 'Team Teaching' as an intervention strategy for international students enrolled in a university-level business course in Australia. The team teaching examined here aims to assist students with the successful completion of two assessment tasks: an argumentative/persuasive essay and a business report. Teaching was focused on structure, key language aspects and referencing. A survey was conducted of lecturers and students both at undergraduate and Master levels from six classes to identify their perceptions and to measure the evaluations of team teaching including that of the team teacher. Results show that both students and lecturers displayed positive attitudes towards the team teacher and the team teaching itself. While Master students displayed a less receptive attitude towards the content of team teaching than undergraduate students, they showed a positive attitude to the team teacher's expertise at a similar degree to the undergraduate students. While students and lecturers alike perceive many benefits in developing academic writing skills, some issues associated with team teaching have been identified and a few strategic measures are recommended.
\end{abstract}

Index Terms - student and lecturer perceptions on team teaching, assessment tasks, intervention strategy, academic literacy, international students in Australia

\section{INTRODUCTION}

It has been well documented that even if international students gain entry to Western academic universities legitimately by fulfilling the normal English language requirements, they encounter enormous problems doing their assignments (Barthel, 2008, 2012; Bayliss \& Ingram, 2006). Their poor language proficiency can result in frustration for content-area teachers (Stewart \& Perry, 2005). This has happened at a university in Sydney. The university offers business related-courses such as IT, Management, Accounting, and Business Law to mostly international students both at a undergraduate and postgraduate level. A general consensus has thus been reached among academic staff and the management at the university is that it is imperative to integrate effective English language programs such as team teaching into the subject pedagogy for the students. The underlying thrust of team teaching is to embed English language learning into discipline-specific courses.

While definitions of team teaching vary depending on context (Robinson \& Schaible, 1995; Goetz, 2000; Sandholtz, 2000; Bailey, Curtis \& Nunan, 2001; CLIL-AXIS, 2004), in general, team teaching refers to a method where two or more instructors work together over planning, teaching/conducting/delivering and evaluating the learning activities for the same students at the same time for instructional purposes in a particular subject or combination of subjects (Buckley, 2000; Bess, 2000; Hwag, Hemandez \& Vrongistions, 2002; Richards \& Farrell, 2005). Dudley-Evans (2001, p. 266) developed a framework for defining team teaching in an English for Academic Purposes (EAP) context. She categorised three levels of interaction: cooperation, collaboration and team teaching, depending on the extent of the cooperative relationship and various types of cooperation that the EAP teachers can have with subject specialists. Cooperation refers here to a low level of cooperation where the EAP teacher consults the subject-specialist informant about aspects of the content or where the subject specialist consults the EAP teacher on language, writing skills or teaching-related questions. Collaboration occurs when the language teacher and the subject teacher work outside the classroom to devise materials together. Team teaching involves both teachers working together in the same classroom (Dudley-Evans, 2001).

Previous studies on the evaluation of team teaching in a language context have been conducted in two main settings: English as a Foreign Language (EFL) and English as a Second Language (ESL). Much previous research on team teaching has been conducted in an EFL context indicating both negative and positive effects (e.g. Coonan, 2003; Hasegawa; 2008; Igawa, 2009). Team teaching in EFL is typically delivered bilingually. With the growing popularity of what is called 'content-based language teaching' (CBLT), team teaching has been thriving in non-English speaking countries such as Japan (e.g. McConnell, 2000; Stewart \& Perry, 2005; Hasegawa, 2008; Igawa, 2009), and Hong Kong by combining L1 with L2 (e.g. Benoit \& Haugh, 2001). European countries also utilise, 'content and languageintegrated learning' (CLIL) where content is taught by both the L1 content teacher and the L2 native English speaker (language expert) (CLIL-AXIS, 2004).

In an ESL context, a small number of studies on team teaching seem to be conducted. For example, a course at the University of Birmingham in the UK has been taught by a content specialist, and a separate tutorial for dealing with problematic language is directly linked to it and led by a language teacher (Dudley-Evans, 2001). In an ESP field, 
Northcott and Brown (2006) explored how a high degree of cooperation between the subject specialist and the English for Legal Purposes teacher can make a contribution to a very specific training need, in their case to assist legislative translation teams from Central and Eastern European countries involved in European integration related translation activities.

Despite the abundance of previous research on the effect of team teaching in various subjects and language areas of other countries, few studies have explored how team teaching is carried out and perceived by ESL students in Australia. The contributing factors for the lack of team teaching in the Australian context may be because of the lack of funding or local institutional structures. Nevertheless, some previous studies report students' positive evaluations of team teaching, highlighting several advantages (e.g. Hinton \& Downing,1998; Buckley, 2000; Helms, Alvis \& Willis, 2005; Yanamandram \& Noble, 2006) even if some negative feelings of frustration and confusion have also been reported (Buckley, 2000; Goetz, 2000; Helms et al., 2005). However, as Joseph and White (2006, p.1) claim, 'team teaching across disciplines at Australian universities is rare'.

Further, few studies have focused on identifying both academic staff and ESL student perceptions of team teaching delivered by two different experts, one from the 'language' and one from the 'content' area. Most studies on the perceptions of team teaching in Australian tertiary contexts have been carried out on either content- or subject- related team teaching members rather than on a mixture of language and content teachers. For instance, Yanamandram and Noble (2006) examined student experiences and perceptions of team teaching of a large class of undergraduate marketing students at a regional Australian university. Six to ten subject- related teachers were involved in an effort to identify the weaknesses and strengths of the team teaching approach. The results reveal that the majority of the students like the concept of team teaching although it can hinder students' learning if a team fails to act as a cohesive unit and work together to adequately link learning concepts. Another example is seen in the research carried out by Joseph and White (2006). They examined the team teaching experience of two teacher educators at Deakin University who shared a 'deep subject-specific knowledge' in teaching two areas such as music and literacy in the Bachelor of Teaching degree. The study found that their team teaching experience provided the two teacher educators with the opportunity to jointly take on the responsibility for content, delivery and assessment. The teaching enabled both students and the educators to find a fun and a challenging way to link literacy and music and to make social connections (p, 174).

The present paper identifies the evaluations and perceptions of both ESL students at a undergraduate and postgraduate level and teaching staff at a university in Sydney, to evaluate both the team teaching and team teacher in terms of teaching academic writing skills. The team teaching was conducted by various subject lecturers and a study support coordinator who was then the team teacher (and the author). The teaching framework utilised by the team teacher was based on an Australian genre-based approach formulated within a Systemic Functional Linguistics (SFL) orientation.

\section{NAtURe AND PRocess of TeAm Teaching IN THIS RePORT}

The nature of team teaching utilised at the university in Sydney is slightly different from the conventional models of team teaching. Team teaching (hereafter TTg) usually occurs when both the lecturer and the study support coordinator (hereafter team teacher: TTr) work with the same groups of students at the same time. However, here the teaching is planned and delivered quite independently at other times. The main content is delivered by lecturers during normal teaching hours and the language component is taught by the $\mathrm{TTr}$ during tutorials. Lecturers are present during the tutorials, supervising students' behaviour, inputting and reinforcing points pertaining to assessment tasks. Quite a 'weak end model' of TTg (Yanamandram \& Noble, 2006, p. 51) is thus employed at the university in terms of the degree of collaboration, integration between team members and the level of engagement between the TTg and the students in the teaching and learning process. Strictly speaking, the nature of the TTg is 'cooperation' rather than 'co-teaching'.

Prior to team teaching (TTg), lecturers and the team teacher (TTr) briefly discuss and negotiate the time and the nature of assignments described in the course outline. The TTr prepares lessons such as analysing essay questions and organising teaching materials, then designs teaching derived from a SFL framework to help produce critical essays or reports including referencing. The framework enables the TTr to deconstruct the assessment tasks in terms of three aspects of aid or teaching: 'contextual' (i.e. the nature of audience, genre, purpose, and subject matter of the assignment), 'textual' (i.e. structure and the language of the assignment), and 'intertextual' (in-text and end-of-text referencing according to the APA system) (see details Lee, 2006, 2008a, 2008b, 2010). Finally, TTr delivers the material during tutorials while lecturers are present. Although lecturers can provide input with regard to the content and formats of the assignments, mostly they do not intervene, but simply listen to the TTr.

TTg is carried out in 2-3 sessions per semester for approximately an hour each session. Students are usually required to do two main assignments per subject. It is ideal to conduct the TTg two weeks prior to the due date of submission. The teaching targets subjects that rely heavily on typical essay and report formats of assessment tasks and also those which display a high failure rate. In particular, lecturers who teach the subject for the first time are encouraged to be involved in team teaching as they may be experts in their academic disciplines but not all lecturers seem to know about the linguistic needs of the ESL students enrolled in their courses. TTg is organised by either lecturers' or the team teacher's initiations. Finally, 'evaluations' on the TTg are carried out with lecturers using a survey to measure the results (see Appendix 1). 


\section{Methodology}

As presented in Table 1, data were collected from 6 classes throughout the three semesters. A total of 127 students (93 undergraduate students and 34 postgraduate students) participated in the survey. Four lecturers were involved in the team teaching; Lecturer A for MGT 100; lecturer B for ITC 331, and 475; lecturer C for ITC 240 and 540 and lecturer D for MGT 230. The assessment tasks required using two main genres: a business report and a persuasive essay.

TABLE 1:

INFORMATION ABOUT PARTICIPANTS AND THE NATURE OF ASSESSMENT TASKS

\begin{tabular}{|c|c|c|c|}
\hline Time & Subject code and name & Cohort of students & Assessment tasks (weighting) \\
\hline $\begin{array}{l}\text { The first semester, } 2009 \\
\text { Lecturer A }\end{array}$ & $\begin{array}{l}\text { MGT } 100 \text { Organisation and } \\
\text { Management }\end{array}$ & $\begin{array}{l}21 \\
\mathrm{UG}(\mathrm{BAC})\end{array}$ & $\begin{array}{l}\text { A case study report } \\
\text { Assessment } 2(35 \%) \\
3000 \text { words }\end{array}$ \\
\hline \multirow{2}{*}{ Lecturer B } & $\begin{array}{l}\text { ITC } 331 \text { Security Privacy and } \\
\text { Ethics }\end{array}$ & $\begin{array}{l}27 \\
\text { UG (BIT) }\end{array}$ & $\begin{array}{l}\text { A persuasive essay: Discussion } \\
\text { Assessment } 2(25 \%) \\
2000 \text { words }\end{array}$ \\
\hline & $\begin{array}{l}\text { ITC } 475 \text { Ethics and Information } \\
\text { Technology }\end{array}$ & $\begin{array}{l}15 \\
\text { PG (MIT) }\end{array}$ & $\begin{array}{l}\text { A persuasive essay: Problem- Solution } \\
\text { Assessment } 2(30 \%) \\
1500 \text { words }\end{array}$ \\
\hline \multirow{2}{*}{$\begin{array}{l}\text { The second semester, } 2009 \\
\text { Lecturer C }\end{array}$} & $\begin{array}{l}\text { ITC } 240 \text { ITC Infrastructure } \\
\text { Management }\end{array}$ & $\begin{array}{l}20 \\
\text { UG (BIT) }\end{array}$ & $\begin{array}{l}\text { Report writing } \\
\text { Assessment } 2(20 \%) \\
2000 \text { words }\end{array}$ \\
\hline & $\begin{array}{l}\text { ITC } 540 \text { ITC Infrastructure } \\
\text { Management }\end{array}$ & $\begin{array}{l}19 \\
\text { PG (MIT) }\end{array}$ & $\begin{array}{l}\text { Report writing } \\
\text { Assessment } 2(20 \%) \\
2000 \text { words }\end{array}$ \\
\hline $\begin{array}{l}\text { The first semester, } 2010 \\
\text { Lecturer D }\end{array}$ & $\begin{array}{l}\text { MGT } 230 \text { Ethics, Sustainability } \\
\text { and culture }\end{array}$ & $\begin{array}{l}25 \\
\mathrm{UG}(\mathrm{BBS})\end{array}$ & $\begin{array}{l}\text { A persuasive essay: opinion } \\
\text { Assessment } 2(20 \%) \\
2000 \text { words }\end{array}$ \\
\hline Total & 6 classes & 127 & \\
\hline
\end{tabular}

The survey questionnaires were constructed and further refined and amended by the team teacher (see Appendix A). The survey consisted of two parts: The first was designed to identify demographic information such as gender, age, country of origin, major, and length of English education in both the students' country of origin and in Australia. The classes were male dominated, as respondents were 103 male and 24 female international students aged between 20-25 years. The postgraduate class had a much older demographic than the undergraduate class. The majority of students were from Nepal, India, and Vietnam, SriLanka, and China. Others were from the Philippines, Uzbekistan, Pakistan, Russia, Lebanon, South Korea and Indonesia. Most students were majoring in Accounting, IT and Business areas. An average length of study at CSUSC is one and a half years. The length of English education received back in their own country averaged six (6) years. After arrival in Australia, on average, students spent one year and three months learning English. Of the 34 Master students, 20 did not have any experience learning English in Australia, indicating that most Master students gained direct entry to CSUSC.

The second comprised three sections. The first aimed to identify student perceptions of the content of team teaching and contained 14 closed questions in relation to the degrees of improvement in contextual (Qs 1, 2); textual (Qs 3-8) and intertextual knowledge (Qs 11-14) along with overall perceived impressions on team teaching (Qs 9, 10). The second consisted of 8 questions designed to evaluate the manner of team teacher comprised of attitude towards students (Qs 1-3, 7), the appropriateness of delivering lessons (Qs 4, 5, 6) and the expertise of the teacher (Q 7). The response scale for the first and second sections was based on the 'Likert' scale containing five items with respect to the degree of agreement or disagreement. Participants were asked to indicate: Strongly Agree (1); Agree (2); Neutral (3); Disagree (4); and Strongly Disagree (5). The lower the number chosen, the more positive an attitude they showed. The third section comprised 5 open questions focusing on the strengths and weaknesses of the team teaching and inviting suggestions. The survey questionnaire is attached in Appendix A.

The survey was also conducted among the lecturers. The first part was the demographic survey which included disciplinary areas in which they taught during the study, the name of subject taught, the length of employment at CSUSC, the length of teaching experience at tertiary level and the type of employment (full time, casual). The second part also contained three sections with identical questions to those asked of the students, differing only in the third section, which consisted of 9 open questions. In that section, the questions were the same as those asked of the students (Qs 5-9). Lecturers were also asked about the perceived importance of team teaching (Qs 1), the differences between the classes or assignments taught by team teaching and the classes or assignments with no team teaching (Qs 2), the differences between the quality of student essays pre- and post- team teaching (Qs 3), and the degree of benefit that the lecturers gained from team teaching (Qs 4). Lecturers were also interviewed by the team teacher using open questions and the results were transcribed for the analysis.

After ethic approvals from the faculty, data were collected throughout three semesters with permission from the lecturers and students. The survey of students was conducted shortly after team teaching. The survey of lecturers was conducted after the final marking of students' assessments. Data from sections 1 and 2 were collated using MS Excel 
and an overall average of mean scores was calculated to find any noticeable differences between sections, across and within the three approaches of contextual, textual, and intertextual as well as among the six classes. Regarding the open questions in section 3, thematic analysis of the data was manually carried out to categorise frequently recurring themes and words that students used and also to identify relationships among the categories.

\section{StUdent PeRceptions}

\section{A. Perceptions of the Content of Team Teaching (Section 1)}

As seen in Table 2, results indicate that student perceptions of the content of team teaching (TTg) and the team teacher (TTr) were quite positive in that a majority of students agreed with the questions (Average Mean (AM) score 1.9). Students evaluated the TTr's manner of delivering the teaching (AM 1.7) much higher than the content (AM 2.0). Students benefited most in gaining intertextual knowledge through TTg (AM 1.8) compared to other aspects of knowledge such as contextual (AM 2.0) and textual knowledge (AM 2.1). Students also expressed quite high degrees of satisfaction about overall TTg in that it helped boost their confidence about writing a report or a persuasive essay (AM 2.2) and helped to prepare them to do their assignments (AM 2.1). Among the six classes, ITC 331 undergraduate students were the most receptive towards TTg (AM=1.6), followed by ITC 240 (AM 1.9) and MGT230 (AM 1.9). Undergraduate students showed much higher satisfaction ratings $(\mathrm{AM} 1.9=2.0+1.8+1.9+1.9 / 4)$ compared to postgraduate students (AM $2.2=2.3+2.0 / 2)$ (see Table 2$)$.

TABLE 2:

STUDENT PERCEPTIONS OF TEAM TEACHING AND THE TEACHER

\begin{tabular}{|l|l|l|l|}
\hline & $\begin{array}{l}\text { Student perceptions on the content of } \\
\text { team teaching }\end{array}$ & $\begin{array}{l}\text { Student perceptions on the team } \\
\text { teacher }\end{array}$ & Average \\
\hline MGT 100 (UG): 21 & 2.0 & 1.9 & 2.0 \\
\hline $\begin{array}{l}\text { ITC 331 } \\
\text { (UG): } 27:\end{array}$ & 1.8 & 1.4 & 1.6 \\
\hline $\begin{array}{l}\text { ITC 240 } \\
\text { (UG): } 15\end{array}$ & 1.9 & 1.8 & 1.9 \\
\hline $\begin{array}{l}\text { MGT 230 } \\
\text { (UG): } 20\end{array}$ & 1.9 & 1.8 & 1.9 \\
\hline $\begin{array}{l}\text { ITC 540 } \\
\text { (PG): } 19\end{array}$ & 2.0 & 1.8 & 1.9 \\
\hline $\begin{array}{l}\text { ITC 475 } \\
\text { (PG): } 25\end{array}$ & 2.3 & 1.7 & 2.0 \\
\hline Total: 127 & Average 2.0 & Average 1.7 & Average 1.9 \\
\hline
\end{tabular}

The greatest differences between undergraduate and postgraduate students can be found in the areas of giving confidence (UG1.9 vs. PG 2.7), helping to avoid plagiarism (UG1.8 vs. PG 2.4), audience awareness (1.9 vs. 2.4 ) and location of evidence in relation to overall structure (1.9 vs. 2.3). These differences arose because Master students agreed less that TTg helps to boost their confidence in writing their assignments (2.7) along with referencing (2.4) and report structure (2.3).

\section{B. Student Evaluations of the Team Teacher (Section 2)}

Students were overall very satisfied with the manner in which the team teaching (TTg) was delivered (AM 1.7). In particular, students most strongly agreed that the team teacher (TTr) seems to have professional knowledge (AM 1.4). The students believed that the TTr was well prepared for classes (AM 1.6). Students agreed less that the teacher presented the lessons clearly (AM 1.8) and made the lesson interesting (AM 1.8). The most noticeable result was that although Master students were the least receptive to the content of TTg, they displayed a significantly different attitude towards the TTr (PG AM 1.75=1.7+1.8/2) indicating a similar degree of satisfaction as undergraduate students (UG AM 1.7=1.9+1.4+1.8+1.8/4) (see Table 2). The result that Master students are less receptive to the content but have a strong positive attitude towards the TTr can be interpreted in several ways. It is possible that, being older students, they are less receptive to acquiring new knowledge due to fossilization effect (Han, 2004). The fact that many Master students received English education only in their birth country indicates they are not well scaffolded for learning higher levels of language skills such as paraphrasing skills including referencing. They are deprived of being exposed to English preparatory courses in Australia. Further, as team teaching in this context is quite intensively condensed in terms of content, it requires high levels of assumed knowledge about essay writing skills Therefore, there is a possibility that the Master students were not well prepared to receive TTg and yet they are very novel about the pedagogy. This result is consistent with the course lecturer B's comments on the Masters' class. This lecturer mentioned that this class (ITC 475) was the least enthusiastic class that he has ever had. Although they are Master students, their levels of English and attitudes are far behind the undergraduate class. Again, the reason for this may be attributable to the big gap between the Master students' linguistic and rhetorical knowledge and the requirements of assignments. In other words, while lecturers have high expectations towards Master students, the students do not seem to be willing to acquire the skills necessary to fulfil these expectations. 


\section{Analysis of Open Questions (Section 3)}

Hundred students responded to the open questions. Regarding Q 1which inquiries into their general feelings or challenges about the style of essay writing in Australia compared to their own countries, the most frequent answers included: being 'different' in terms of references, structure, formality, 'difficult', and 'challenging' relating to requiring more knowledge, ideas and learning. However, a number of students said that there seemed to be no differences between essay writing in English and their own countries but commented that the referencing is very different. The former is possible because quite a large number of students (64\%) at the university are 'pathway' students who have already studied in institutions such as colleges and Technical and Further Education) (TAFE) in Australia which use English as a medium for instruction before enrolling at the university. The major differences and difficulties are attributable to referencing, structure, grammar and vocabulary, technicality or formality. Lecturers' high expectations are also seen as a minor contributor to their perceived differences. The response is consistent with the Likert-scale results that students received most benefits in the learning of referencing through team teaching. This confirms that a major concern for students is referencing alongside plagiarism because the referencing system is quite novel to the students. The following response from a student reflects the main difference between Australia and the student's native language in terms of referencing:

Essay writing is quite challenging here in Australia. Referencing is not really recommended in our country. But it is a major part which I have learned here (A student from ITC 475).

Students' perceived team teaching as assisting them to gain not only practical skills but also cognitive and social benefits. A majority of students answered that team teaching helped them to improve their skills practically and increased their writing skills. Answers are indicated in Table 3.

TABLE 3:

STUDENTS' PERCEIVED BENEFITS OF TEAM TEACHING

\begin{tabular}{|l|c|}
\hline Reasons for benefits & Number \\
\hline learn about "proper formats" of report and essay writing & $(19)$ \\
\hline "Referencing" & $(13)$ \\
\hline "improve writing skills and style" so that they can write essays more "easily" and "efficiently" & $(12)$ \\
\hline "understand better, clearly, and more thoroughly" & $(10)$ \\
\hline "gain in-depth knowledge" and a better idea about essay writing. & $(8)$ \\
\hline "learn different ways" of writing essays , & $(9)$ \\
\hline learn "new" things about essay writing. & $(9)$ \\
\hline facilitates "interaction and group discussion" & $(6)$ \\
\hline "share their views and opinions" & $(4)$ \\
\hline "having fun" and encouragement. & $(4)$ \\
\hline Others & $(6)$ \\
\hline Total & $(100)$ \\
\hline
\end{tabular}

The frequency of comments on learning new and different ways of writing essays implies that the team teacher's ways of teaching make good sense to these students in understanding and interpreting the nature of assessment tasks and how the tasks are addressed. Other benefits include learning better collectively, gaining maximum marks, building confidence, and identifying negative aspects of their writing problems, etc. Only one student said team teaching was "nothing more than making me confused with report writing and references".

The students' positive attitude toward TTg is supported by empirical data. MGT 230 can be taken as an example to demonstrate this claim. The course requires doing two main assignments: assessment 1 (Hereafter Ass 1) and assessment 2 (Ass 2). TTg was conducted on the Ass 2 only. Most students showed marked improvement in their assignments an average of 6 marks more than their score on Ass 1 (on average 58) for Ass 2 (on average 64). While acknowledging that many factors contributed to this increase, it is inferred that if TTg had not been offered, some students might have received fail marks. It is clear that those who utilised TTg improved a great deal but those who did not, tended to receive similar marks or reduced marks. After TTg, students were strongly encouraged to receive individual consultations by the lecturer. Along with TTg, those students who received individual consultations show remarkable improvement in their Ass 2, showing 14 marks difference on average (Ass 1, 52 vs. Ass 2, 66). Individual consultations are available by booking from the students who wish to have the drafts of their assignments checked by the team teacher before submission. Most students end up receiving at least two sessions to be able to produce a quality of their assignments at a presentable level.

With regard to the problems with TTg, although a large number of students (29) said they "could not find any problems" and it is "satisfactory", "interesting" and "fun", some weaknesses were identified with team teaching. Students' perceived weaknesses of team teaching include the "lack of attention to the individual needs" according to their levels, the classes being "noisy" and "distractive" because of "too many people" in the class and being "too lengthy", "without breaks". It also includes "being given too much knowledge at one time", "not enough time" and "resources" and students" having "little chance to make contributions". A couple of students note "understanding the team teacher's language" including communication problems in dealing with students from different cultures. Commonalities among the weaknesses seem to be associated with the teaching intensity due to time constraints. 
Suggestions by students align with the limitations of TTg. While many students (15) expressed their views that team teaching was "satisfactory" with "overall a good learning experience", some specific suggestions were made. These include conducting team teaching more "frequently", "on a regular basis", "continuously" and with a shorter duration (25). Some students stated this quite strongly saying, "it should be compulsory for students to attend at least one class about essay writing" by "forcing students to attend the class". Similarly, they should receive more detailed knowledge by attending writing workshops. The second most frequent suggestion was "to divide the class into small groups" to "avoid unattentive students", to "share information", and to meet "students" individual needs" and levels (19). The next most frequent suggestion was that "more practice" is needed through "exercise", and "examples". Also more "handouts", "visual aids", "charts", "laptop videos", "more detailed line upon line concepts" (4) should be given and used to "help them to understand clearly" (3).

\section{LECTURERS' PERCEPTIONS}

Two lecturers out of the four responded. They are from MGT100 (lecturer A) and ITC 331 (lecturer B) who taught in the first semester. Both are Australian native speakers of English. While A's length of employment at CSUSC is 2 years, $\mathrm{B}$ has more than 10 years. The findings were very similar to those in relation to students. Regarding the content of team teaching, overall the teachers' perceptions were much more positive than the students (1.1). A was more positive (1.0) than B (1.1).The lecturer A agreed strongly to all questions except one. B also showed a very positive attitude to most major questions but a slight reservation was made regarding questions 1, 2, 3, in section 2 which are all related to the contextual knowledge of essay writing. Both of them gave a most positive response towards the team teacher (1.0). A limitation which must be considered is the fact that the researcher/team teacher was involved in the team teaching project under examination and subsequently the conduct of the survey. Therefore, the results may not be a $100 \%$ accurate reflection of their attitude.

Regarding Q1 in section 3 (How important do you think team teaching is in terms of helping students' to cope with assignments?), both lecturers perceived that team teaching was vitally important because it helped the students to be more "positive" and "confident" as well as "understand" the requirements of the assignment. It acted as a catalyst for students to utilise further assistance by realising "there is support available for them". Regarding Q2 (Are there any differences you can notice between classes with team teaching and classes with no team teaching in terms of students' improvement?), both lecturers agreed that students can improve significantly through team teaching. They discovered "positive differences in student grades" (A) and that "students do submit better assignments' (B). The ITC lecturer B stated that "after team teaching, on average, 10-15\% of student marks has increased because of the improvement in the formats compared to last year" when team teaching was not conducted. Regarding Q3 (Have you noticed any differences between before team teaching and after team teaching in terms of the quality of the assignments students provided?), differences were noticed in the referencing in particular but again students needed to "apply the new learning".

Regarding Q4 (How much does team teaching help you to learn some new skills or refresh your skills with regard to writing an essay and referencing?), both lecturers agree that team teaching can also bring some benefits to them by "learning interesting points and strategies", in "creating writers' voice". They stated that they would use "this learning in their teaching". In fact, based on personal experience, not all lecturers, especially casual lecturers, seem to know the finer points of academic integrity, in particular, with regards to the current and correct format of referencing along with academic literacy. Both lecturers pointed out that a major problem in students' writing was related to referencing associated with plagiarism (Q5). This result was also in accord with the students' responses that referencing is a key challenge for them and in turn, they learn the most about referencing through the team teaching. Regarding the strengths of team teaching (Q6), A answered that it teaches "relevant" and useful skills to help students improve the quality of their papers". Lecturer B answered that it gives "on the ground support" by following "where the students are and does not wait for the students to seek help". Regarding the weaknesses of team teaching (Q7), lecturer A noted that team teaching needs to provide more 'practical examples' and 'exercises', in particular, with regard to 'in-text referencing'. More frequent visits of a short duration by the team teacher would be a better intervention strategy. Both suggested giving mini assessments or small exercises so that students can practise the new skills they learned to ensure they understand the key points.

\section{DISCUSSION AND ISSUES}

Results reveal that team teaching has been perceived as being fruitful by both students and staff although the 2-3 hours total sessions allocated are insufficient to claim the significant changes. While lecturers show more positive attitudes than students, they all appreciate the team teacher's personal expertise on academic skills more than the content itself (1.7 vs. 2.0). Such positive results are consistent with a number of advantages documented in the team teaching literature. These include its efficiency and self- efficacy by teaching students collectively (McDaniel \& Colarulli, 1997). Variation in teaching styles and/or method of presentation by combined expertise of teachers motivates students to increase their interest in learning. It promotes collegiality among teachers in a school (Yanamandaram \& Nobel, 2006; Team teaching, n. d; Richards \& Farrell, 2005). It also appears that it provides lecturers with opportunities 
to acquire and improve their teaching of academic writing skills, especially in referencing without losing face. Richards \& Farrell (2005) point out that team teaching itself could be viewed as a teachers' professional development opportunity. The lecturers agree that team teaching helps them to better understand the assignment criteria from a linguistic perspective, which results in the subsequent development of effective guidance for student assignments. Most importantly, as team teaching is integrated into subject-related content, team teaching seems to be a catalyst for students' subsequent engagement in other study support programs such as workshops and individual consultations. Students in general are often not aware of the existence of the study support programs or even if they are aware, they are not well motivated to utilise the program. When they are given opportunities to develop 'rhetorical awareness' of their studies in general by being exposed to rhetorical and linguistic expectations through team teaching, they begin to adopt a more active role in seeking help (Dudley-Evans, 2001, p, 228).

Despite the relatively positive perceptions and the potential benefits for all concerned, some weaknesses were identified. These weaknesses, such as the classes being noisy and distractive and too long, and students being given too much knowledge at the one time and being given little chance to make contributions are possibly instrumental in contributing to the wide discrepancy between the input of the team teaching and the real output of the students, though other reasons can be cited for the gap. Although lecturers responded that improvement could be seen in students' results after team teaching, they identified a problem by saying "it all depends on the degree to which students can put their learning into practice". Students do not all learn at the same rate. Some students do not seem to be keen enough or to have the ability to fully utilise what they have learned. This is especially true of the Master levels of students who gained direct entry to the course. These students had only received English instruction/education in their own country. The English they learned often bears little resemblance to grammatically and rhetorically appropriate writing suitable for an academic genre. Yet they believe they are proficient in English. Further, because team teaching is intensive and requires strong 'shared assumptions' or 'scaffolding' about language learning, some students find it difficult to digest and implement the knowledge in their assignments.

One cause of the discrepancy is lack of direct engagement between students and the team teacher which can be a severe disadvantage of team teaching from the perspective of achieving pedagogical goals if 'joint construction' between a teacher and a student writer can be considered lacking in the process of the teaching/learning cycle (Burns, 2001). Team teaching is still seen as no more than a mechanism of the presentation phase in the 'presentation-practice-production (ppp)/teaching/learning cycle' (Nunan, 2004). In order for students to fully maximise their results, they have to go through the subsequent phases of practice and production and through individual interactions between students and the writing supporter.

Another related weakness was that team teaching leads some students to become confused. One source of confusion stems from the fact that lecturers and the team teacher occasionally contradict each other in interpreting assignments in terms of formats and referencing style. This tends to happen when assessment guidelines do not state clearly the required format such as a hybrid genre between a report and an essay. One student's response illustrates this point when he explains that he can become confused by the conflicting opinions of the team teacher and lecturer. Some lecturers, especially casual lecturers, do not seem to have a clear understanding of genre and referencing. Some of them are not flexible about the format required. This situation can be a source of conflict between the team teacher and the subject teachers. The conflict is exacerbated by the fact that the school uses a weak form of team teaching. Consequently, not much prior discussion about assignments is made between the team teacher and lecturers. As Yanamandram and Noble (2006) point out, losing trust and respect between lecturers and the team teacher can impede students' learning. Student confusion may also be caused by the condensed and intense nature of team teaching. The team teacher uses a relatively teacher- directed 'top-heavy approach' as there is often insufficient time in the classes to cover all aspects of writing skills in guiding assignments. .

Team teaching also can inadvertently encourage a form of plagiarism. This weakness may be due to the genre-based approach that the team teacher used. Despite its numerous benefits (e.g. Hyland, 2007; Bruce, 2008; Bawarshi \& Reiff, 2010), one main disadvantage is that its main focus is on structure rather than on content, "overlooking natural processes of learning and writers' creativity” (Badger \& White, 2000, p.157; Bawarshi, 2003; Byram, 2004). This can result in a unified, fixed and product-focused model rather than encouraging a flexible, evolving and process oriented model (Johns, 2011). This method may thus lead poorly performing students to adopt 'helpless plagiarism' (Lee, 2010) where students resort to the team teacher's instructions without alteration due to their inability to rework others' work. Further, given time constraints, team teaching cannot cover all aspects of assessment criteria such as grammar in detail, or substantial content, which is a main contributor to the quality of an assessment.

\section{CONCLUSION AND RECOMMENDATIONS}

This paper attempts to identify student and staff feelings about a study intervention program of team teaching as well as reporting students' suggestions for improvement. While implementing team teaching within an academic context is very useful in many aspects, the paper identified some major weaknesses such as lack of individual attention, exercise practice and distractions. Other weaknesses identified by students and lecturers include a gap between teaching and the students' inability to apply the teaching in assignments especially from poorly performing students, confusion, conflicts and plagiarism. 
Given the issues identified and suggestions made by lecturers and students, the following recommendations can be made for the better implementation of team teaching.

- The less positive attitude shown by Master students indicates the need for the effective provision of team teaching resources and further language intervention strategy for those students, in particular, those who gain direct entry to the universities. The Master students' struggles seem to arise from the gaps between their existing levels of writing proficiency and high expectations and requirements of the university.

- To ensure the effective delivery of team teaching, more frequent contact with the team teacher together with a shorter duration of team teaching such as implementing a drop in session should be embedded into the teaching. Further, lecturers and the university authority strongly believe that study support programs such as essay writing workshops and individual consultations where students can have opportunities of hands on exercises and practices can improve their results and reduce plagiarism.

- To help reduce conflict between lecturers and team teachers and students, it is essential to run a teacher development program. For better team teaching, professional development is important (Richards \& Farrell, 2005). Teacher development programs will enhance academic literacy and hone skills of lecturers such as learning metalanguages used for interpreting assessments, updating reference skills, and understanding genres and related marking criteria. The team teacher needs to work closely with content lecturers regarding the focus of the team teaching before class so that lecturers can be well informed of what will be covered by the team teacher. Explicit and clear articulations of assessment guidelines by convenors on the course outlines would also be helpful for easing the conflict.

More research is needed on the topic of team teaching including interviews over an extended research period to identify data for evaluation, in particular, targeting master students. Investigation of the differences in academic results between students exposed to team teaching and those who are not should be considered a priority for further research projects.

\section{Appendix A. Team Teaching Evaluation on the RePORT Writing-STUdENTS}

\section{Part I}

Please tick $\sqrt{ }$ boxes

Gender: $\quad \mathrm{F} \square \quad \mathrm{M} \square$

Country of origin:

Major: BIT $\square$; BB $\square$; BAC $\square$; MIT $\square$; MB $\square$; MAC $\square$

Length of study at the university:

Length of English education in your country prior to coming to Australia:

Year ( ) and Month ( )

Length of English education in Australia prior to the entry of the university:

Year ( ) and Month ( )

\section{Part II}

Please answer questions on team teaching, as they will be confidential and will help us guide the revision of the content of team teaching in the future.

Circle the letters that correspond with your opinion for each statement.

$\mathrm{SA}=$ Strongly agree $\mathrm{A}=$ agree $\mathrm{N}=$ no opinion $\mathrm{D}=$ disagree $\mathrm{SD}=$ strongly disagree

\section{A: About the content of team teaching}

1. Was the purpose of writing a report clear.

2. Are you aware of the audience and their expectations.

3. Do you know about report structures.

4. You have a better understanding of how to write an executive summary.

$\begin{array}{ccccc}\text { SA } & \text { A } & \text { N } & \text { D } & \text { SD } \\ \text { SA } & \text { A } & \text { N } & \text { D } & \text { SD } \\ \text { SA } & \text { A } & \text { N } & \text { D } & \text { SD } \\ \text { SA } & \text { A } & \text { N } & \text { D } & \text { SD }\end{array}$

5. I understand how to write an introduction to a report, recognizing the different functions between the executive summary and the introduction.

6. I know how to write about methods, findings and conclusions.

7. I know how to write a topic sentence (general claims).

8. I can make recommendations persuasively in a formal manner.

9. Team teaching gave me practice and confidence in my writing a report.

SA $\quad$ A $\quad \mathrm{N} \quad \mathrm{D} \quad \mathrm{SD}$

SA $\quad$ A $\quad$ N $\quad$ D $\quad$ SD

SA $\quad$ A $\quad \mathrm{N} \quad \mathrm{D}$ SD

SA $\quad$ A $\quad$ N $\quad$ D $\quad$ SD

10. Team teaching helped me prepare for my writing assignments (for a report). $\quad$ SA $\quad A \quad$ N $\quad$ D $\quad$ SD

11. I can understand the importance of referencing appropriately in relation to the issues of plagiarism.

12. I acquired a better understanding $\quad$ SA A $N$ D $\quad$ SD

12. I acquired a better understanding of both In-text and End-of-text referencing. $\quad$ SA $\quad$ A $\quad$ N $\quad$ D SD

13. Acquired knowledge and strategies would help to avoid being accused of plagiarism such as writing clear topic sentences (general claims)

SA $\quad \mathrm{A} \quad \mathrm{N} \quad \mathrm{D} \quad \mathrm{SD}$

14. I know where evidence can occur in the overall report structure and the paragraph level of structure.

\section{B: About the team teacher}

1. The teacher had a positive attitude towards the student.

SA A N D SD


2. The teacher was well prepared for classes.

3. The teacher was enthusiastic about teaching.

4. The teacher's lessons were relevant to the assessment tasks and goals.

5. The teacher presented the lessons clearly.

6 . The teacher tried to make the lesson interesting.

7. The teacher cares about the students.

8. The teacher has professional knowledge about essay writing.

C: Please use the space under each of the following questions for further comments:

1. Explain your general feelings or challenges about writing an essay in Australia compared to your country

2. What are your perceived benefits of this team teaching?.

3. Explain some of the problems associated with team teaching?.

4. Please provide suggestions as to how team teaching can be made better in the future.

5. Any other comments?

\section{ACKNOWLEDGEMENT}

I would like to express my sincere gratitude to the Director at Charles Sturt University Study Centre (CSUSC) Sue Bakir and my supervisor Dr. Jeffery Gosper for their strong support in my research. My thanks also extend to the academic staff and students at CSUSC for their cooperation in this research. I am also deeply grateful to John Magin for his proof reading of my paper.

\section{REFERENCES}

[1] Badger, R. \& G. White. (2000). Product, process and genre: Approaches to writing in EAP. ELT Journal, 54.2, $153-160$.

[2] Bailey, K.M., A. Curtis \& D. Nunan. (2001). Pursuing professional development. Singapore: Heinle \& Heinle.

[3] Barthel, A. (2008). 'Preparing for diversity: are universities ready?' AIEC2008, Brisbane Qld, 7-10 October. http://www.aiec.idp.com/pdf/Barthe_\%20Fri_1140_M2.pdf (accessed 6/5/2012).

[4] Barthel, A. (2012). Integrated academic language and learning development for Charles Sturt University. A discussion paper.

[5] Bawarshi, A. (2003). Genre \& the intervention of the writer. Longan: Utah State UP.

[6] Bawarshi, A. S. \& M. J. Reiff. (2010). Genre: An introduction to history, theory, research, and pedagogy. Indiana: Parlor Press.

[7] Bayliss, A. \& D. Ingram. (2006). 'IELTS as a Predictor of Academic Language Performance', AIEC2006, Perth WA, October 2006. http://www.idp.com/aiec (accessed 9/7/2009).

[8] Benoit, R. \& B. Haugh. (2001, October). Team teaching tips for foreign language teachers. The Internet TESL Journal, 6(10). http://iteslj.org/Techniques/Benoit-TeamTeaching.html (accessed 7/10/2010).

[9] Bess, J. L. (2000). Integrating autonomous professionals through team-teaching. In J. L, Bess. (ed.), Teaching alone, teaching together: Transforming the structure of teams for teaching, Jossey-Bass, SanFrancisco: WILEY.

[10] Bruce, I. (2008). Academic writing and genre: A systemic analysis. New York: Continuum international Publishing.

[11] Buckley, F. J. (2000). Team teaching: what, why and how? Thousand Oaks. CA: Sage Publications, Inc.

[12] Burns, A. (2001). Genre-based approaches to writing and beginning adult ESL learners. In C. Candlin \& N. Mercer (eds.), English language teaching in its social context: A reader. London: Routledge, 200-207.

[13] Byram, M. (2004). Genre and genre-based teaching. The Routledge Encyclopaedia of language teaching and learning (pp. 234-237). London: Routledge.

[14] CLIL_AXIS. (2004). Content \& Language Integrated Learning (CLIL)-AXIS team teaching. http://www.cili-xis.net/potential_clil_definitions.htm (accessed 7/10/2010).

[15] Coonan, C.M. (2003, April). Some issues in implementing CLIL, Information Bulletin 9, April.

[16] Dudley-Evans, T. (2001). Team teaching in EAP: Changes and adaptations in the Birmingham approach. In J. Flowerdew \& M. Peacock (eds.), Research perspectives on English for Academic purposes. Cambridge: Cambridge University Press, 225-238.

[17] Goetz, K. (2000). Perspectives on team-teaching, Egallery, 1, 4. http://www.ucalgary.ca/egallery/goetz.htm (accessed9/11/2009).

[18] Hasegawa, H. (2008). Non-native and native speaker teachers' perceptions of a team teaching approach: case of the JET programme. The International Journal of Language Society and Culture, 26, 42-54.

[19] Han, Z. H. (2004). Fossilization in adult second language acquisition. Church point; Australia, Multilingual Matters LTD.

[20] Helms, M. M., J .M. Alvis \& M. Willis. (2005). Planning and implementing shared teaching: MBA team-teaching case study (master of business administration). Journal of Education for Business. September/October, 29-34.

[21] Hinton, S. \& J. Downing. (1998). Team teaching a college core foundations course: Instructors and students' assessments. Richmond, KY: Eastern Kentucky University> ERIC documents NO ED 429469.

[22] Hwag, Y. S., J. Hemandez \& K. Vrongistions. (2002). Elementary teacher education students' perceptions of team teaching. http://www. highbeam.com/doc/1G1-98248720.html (accessed 11/11/2010).

[23] Hyland, K. (2007). Genre pedagogy: language, literacy and L2 writing instruction: Journal of Second Language Writing 16.3, $148-164$.

[24] Igawa, K. (2009). EFL teachers' views on team-teaching: In the case of Japanese Secondary school teachers. The International Journal of Language Society and Culture, 47, 145-172.

[25] Johns, A. M. (2011). The future of genre in L2 writing: Fundamental, but contested, instructional decisions. Journal of Second Language Writing, 20, 56-68. doi: 10.1016/j.jslw.2010.12.003.

[26] Joseph, D. \& S. White. (2006). Team teaching in teacher education: Towards an interdisciplinary approach. Proceedings of the 2006 Australian Teacher Education Association Conference. 
[27] Lee, S. H. (2006). The use of interpersonal resources in argumentative/persuasive essays by East-Asian ESL and Australian tertiary students. $\mathrm{PhD}$ thesis, University of Sydney.

[28] Lee, S. H. (2008a). An integrative framework for the analyses of argumentative/persuasive essays from an interpersonal perspective. Journal of Text and Talk, 28.2, 23-9270.

[29] Lee, S. H. (2008b). The use of interpersonal resources in argumentative/persuasive essays: Cross-cultural and grade-based differences in academic essays by East-Asian ESL and Australian tertiary students. Saarbrücken, Germany: VDM Verlag Dr Müller.

[30] Lee, S. H. (2010). Attribution in high-and low-graded persuasive essays by tertiary students. Journal of Functions of Language, $17.2,181-206$

[31] McConnell, D.L. (2000). Importing diversity: Inside Japan's JET program. Berkeley, CA: University of California Press.

[32] McDaniel, E., \& Colarulli, G. (1997). Collaborative teaching in the face of productivity concerns: The dispersed team model. Innovative Higher Education, 22.1, 19-36.

[33] Northcott, J. \& G. Brown. (2006). Legal translator training: Partnership between teachers of English for legal purposes and legal specialists. Journal of English for Specific Purposes, 25, 358-375. Doi: 10.1016/j.esp.2005.08.003.

[34] Nunan, D. (2004). Task-based language learning. Cambridge: Cambridge University Press.

[35] Richards, J. C., \& T. S. C. Farrell. (2005). Professional development for language teachers: Strategies for teacher learning. Cambridge: Cambridge University Press.

[36] Robinson, B. \& R. M. Schaible. (1995). Collaborative teaching reaping the benefits. College Teaching, 43.2, 57-60.

[37] Sandholtz, J. H. (2000). Interdisciplinary team teaching as a form of professional development. Teacher Education Quarterly, $27.3,39-54$.

[38] Stewart, T. \& B. Perry. (2005). Interdisciplinary team teaching as a model for teacher development. Teaching English as a Second or Foreign Language. TESL-EJ, 9.2, 1-16.

[39] Team teaching. (n.d.). http://www.answers.com/topic/team-teaching. (accessed 6/12/2011).

[40] Yanamandram, V. \& G. Noble. (2006). Student experiences and perceptions of team-teaching in a large undergraduate class. Journal of University Teaching and Learning Practice, 3.1, 49-66.

Sook Hee (Susan) Lee was born in Busan, South Korea on 6 December 1957. She has a Masters degree in Educational Psychology from Busan National University. After she came to Australia in 1991, she also completed a Masters degree in TESOL at the University of Wollongong in 2000 in Australia. She obtained a Ph D degree in TESOL in the Faculty of Education and Social Work at the University of Sydney in 2006.

After the completion of her PhD, she taught IELTS (International English Language Testing System) and EAP (English for Academic Purposes) courses at various colleges. She is currently working at Charles Sturt University Study Centre in Sydney as the Study Support Coordinator. Her main role is to teach students (mostly international) both at undergraduate and Masters' level how to write academic essays. Her main research interests are in the areas of functional grammar, interpersonal meaning including evaluation in essay writing, and intercultural rhetoric.

Dr Sook Hee (Susan) LEE is a member of Association for Academic Language and Learning (AALL) and Systemic Functional Linguistics (SFL). The following is a list of some of her recent publications:

S. H. Lee (2010). Attribution in high-and low-graded persuasive essays by tertiary students. Journal of Functions of Language. $17(2), 181-206$

S. H. Lee (2008a). Attitude in undergraduate persuasive essays. Journal of Prospect. 23 (3), 43-58.

S. H. Lee (2008b). An integrative framework for the analyses of argumentative/persuasive essays from an interpersonal perspective. Journal of Text and Talk. 28 (2), 239-270. 